\title{
APLIKASI EDIBLE COATING BIONANOKOMPOSIT UNTUK PRODUK PEMPEK PADA PENYIMPANAN SUHU RUANG
}

\author{
[Application of Bionanocomposite Edible Coating on Pempek \\ during Storage at Room Temperature]
}

\author{
Mona Nur Moulia ${ }^{1)}$, Rizal Syarief ${ }^{1)}$, Nugraha Edhi Suyatma ${ }^{1) \star}$, Evi Savitri Iriani ${ }^{3)}$, dan Harsi \\ Dewantari Kusumaningrum ${ }^{1)}$ \\ 1) Departemen Ilmu dan Teknologi Pangan, Fakultas Teknologi Pertanian, Institut Pertanian Bogor, Bogor \\ 2) Balai Besar Penelitian dan Pengembangan Pascapanen Pertanian, Bogor
}

Diterima 4 Mei 2018 / Disetujui 27 November 2018

\begin{abstract}
Edible packaging is a relatively new technology for food preservation, many research on edible coating had been conducted and it proved to prolong storage life and to improve the quality of food products. The main objective of this research was to investigate the shelf-life of pempek coated with edible bionanocomposite made from cassava starch, zinc oxide nanoparticles ( $\mathrm{ZnO}-\mathrm{NPs}$ ) and garlic extract. Bionanocomposite edible coating Z3B20 (containing ZnO-NPs 3\% and garlic extract 20\%) and Z3B30 (ZnO-NPs 3\% and garlic extract 20\%) were applied on pempek products. The parameters observed were total microbes, total Staphylococcus aureus, texture, total volatile nitrogen (TVN), moisture content, $\mathrm{pH}$ during storage at room temperature for 0, 6, 24 and 48 hours. The results showed that the total microbe numbers increased during the storage. Pempek coated with Z3B20 has a total microbes of $6.00 \mathrm{log} C F U / g$ which was lower than that of control (6.99 log CFU/g). Meanwhile pempek coated with Z3B30 has Staphylococcus aureus counts of $2.93 \mathrm{log}$ CFU/g which was lower than the control (4.05 log CFU/g) and pempek coated with Z3B30 stored for 48 hours (3.64 log CFU/g). The TVN values increased during storage from $17.33 \mathrm{mg} / 100 \mathrm{~g}$ to $18.94 \mathrm{mg} / 100 \mathrm{~g}$ while those in Z2B30 and Z3B30 decreased to 14.80 $\mathrm{mg} / 100 \mathrm{~g}$ in Z3B30, respectively. The hardness increased during storage from $9.93 \mathrm{~N}$ in control, to $10.01 \mathrm{~N}$ in Z2B30 and 13.15N in Z3B30, respectively. All coated pempeks after storage up to 48 hours had higher moisture contents. On the other hand, the $\mathrm{pHs}$ decreased for all samples during storage. Based on the total microbe numbers and TVN values, it can be concluded that the coated pempek stored for 24-hour or less were acceptable for consumption.
\end{abstract}

Keywords: bionanocomposite, garlic extract, pempek, room storage, zink oxide

\begin{abstract}
ABSTRAK
Pengemasan dengan edible coating merupakan salah satu pengawetan pangan yang relatif baru, yang telah banyak dilakukan dan terbukti dapat memperpanjang masa simpan dan memperbaiki kualitas produk pangan. Penambahan nanopartikel zinc oksida (NP-ZnO) dan ekstrak bawang putih ke dalam larutan edible coating pati ubi kayu bertujuan untuk mengetahui pengaruh aplikasi edible coating terhadap kualitas dan umur simpan pempek yang disimpan pada suhu ruang. Bionanokomposit edible coating dengan kombinasi (1) 3\% NP-ZnO dan 20\% ekstrak bawang putih (Z3B20) dan (2) 3\% NP-ZnO dan 30\% ekstrak bawang putih (Z3B30) telah diaplikas ikan pada pempek melalui metode celup selama 30 detik dan kemudian dikeringanginkan. Variabel yang diukur adalah total jumlah mikroba, total Staphylococcus aureus, tekstur, total volatil nitrogen (TVN), kadar air, dan $\mathrm{pH}$ selama pempek disimpan pada suhu ruang selama 0,6, 24 dan 48 jam. Hasil penelitian menunjukkan bahwa selama penyimpanan pempek yang diberi perlakuan coating Z3B30 memiliki total mikroba sebesar 6,00 log CFU/g, lebih sedikit dibandingkan dengan kontrol (6,99 log CFU/g). Jumlah koloni Staphylococcus aureus pada pempek yang diberi perlakuan coating Z3B20 (2,93 log CFU/g) lebih sedikit dibandingkan kontrol (4,05 log CFU/g) dan Z3B30 (3,64 log CFU/g) pada jam ke-48. Nilai TVN meningkat dari 17,33 mg/100 g (kontrol) menjadi 18,94 $\mathrm{mg} / 100 \mathrm{~g}$ (Z2B30) tetapi menurun menjadi 14,80 mg/100 g (Z3B30). Nilai hardness meningkat dari 9,93 N (kontrol) menjadi 10,01 N (Z2B30) dan 13,15 N (Z3B30). Kadar air sampai dengan jam ke-48 meningkat untuk semua sample. Sebaliknya, nilai pH menurun untuk semua perlakuan. Berdasarkan total jumlah mikroba dan nilai TVN, maka dapat disimpulkan bahwa pempek dengan masa simpan $\leq 24$ jam masih layak dikonsumsi.
\end{abstract}

Kata kunci: bionanokomposit, ekstrak bawang putih, nanopartikel seng oksida, pempek, suhu ruang

*Penulis Korespondensi:

E-mail: nugrahaedhi@yahoo.com; mona_nurm@yahoo.com 


\section{PENDAHULUAN}

Edible coating merupakan proses pelapisan dari bahan dapat dimakan yang diaplikasikan langsung ke permukaan produk baik melalui metode semprot, celup atau tetes sehingga berfungsi sebagai pengemas atau pelapis makanan yang sekaligus dapat dimakan bersama dengan produk yang dikemas. Edible coating berfungsi untuk memperpanjang umur simpan, sebagai pembawa komponen makanan diantaranya pengawet, antioksidan, vitamin, mineral, antimikroba, bahan untuk memperbaiki rasa dan warna produk yang dikemas.

Bahan edible coating yang paling banyak digunakan dari golongan polisakarida adalah pati, salah satunya adalah pati ubi kayu. Keunggulan edible coating berbasis pati adalah dapat mencegah dehidrasi, oksidasi lemak, mengurangi laju respirasi dengan mengontrol komposisi gas $\mathrm{O}_{2}$ dan $\mathrm{CO}_{2}$ dalam atmosfir internal serta mencegah pencoklatan pada permukaan produk yang dilapisi. Selain keunggulan tersebut, edible coating berbasis pati juga memiliki kelemahan, salah satunya adalah resistensinya terhadap air rendah karena sifat hidrofilik dari pati (Garcia et al., 2011).

Salah satu cara untuk memperbaiki karakteristik edible coating adalah menambahkan bahan pengisi berukuran nano, seperti nanopartikel zinc oksida (NP-ZnO), ke dalam biopolimer sehingga terbentuk polimer nanokomposit serta penambahan bahan alami ekstrak bawang putih untuk meningkatkan aktivitas antibakteri larutan edible coating. Bionanokomposit adalah komposit yang tersusun dari matriks polimer alami dan pengisi berupa materi yang berskala nano. Bionanokomposit juga dapat diperoleh dari dua atau lebih bahan pengisi berskala nano; misalnya, bahan dari sumber yang dapat diperbaharui (renewable) dan dari bahan sintetik atau inorganik seperti polipropilen, polivinilklorida dan lain-lain (Rathore dan Pradhan, 2017).

Bionanokomposit edible coating dapat diaplikasikan pada produk pangan, salah satunya pempek. Pempek merupakan makanan khas Palembang, Provinsi Sumatera Selatan yang memiliki proses pengolahan tanpa menggunakan bahan pengawet, sehingga proses pengemasan tradisional menyebabkan umur simpan pempek hanya sekitar sehari jika penyimpanan dilakukan pada suhu ruang. Penyimpanan lebih dari 16 jam menyebabkan pembentukan lendir pada permukaan produk, citarasa yang tidak enak, dan pertumbuhan bakteri; terutama Staphylococcus aureus (Pratama et al., 2016).

Pempek terbuat dari beberapa bahan dasar seperti tepung, daging ikan dan bawang putih sebagai salah satu rempah-rempah. Pempek mengandung air $58,59 \%$, protein $15,84 \%$, karbohidrat $20,17 \%$, lemak $1,41 \%$ dan abu 1,57\% (Rosdiana, 2002). Komponen-komponen tersebut menyebabkan pem- pek mudah mengalami kerusakan. Hasil penelitian Karneta et al. (2013) menunjukkan pempek dengan komposisi $39,7 \%$ berasal dari ikan dan disimpan pada suhu ruang hanya mampu bertahan selama satu hari. Kerusakan atau kemunduran mutu pempek ditandai dengan perubahan pada tekstur pempek, terbentuk lendir pada permukaan, warna pempek berubah menjadi kuning atau kecoklatan, timbul bau busuk dan penurunan pH. Ketetapan batas keberadaan mikroba pada pempek, terutama bakteri patogen, menurut ketentuan Badan Pengawas Obat dan Makanan (BPOM) No. HK 00061524011 tahun 2009 untuk produk perikanan yang dikukus atau direbus maksimum sebesar $<3 \mathrm{CFU} / \mathrm{g}$ untuk Escherichia coli, negatif/25 g untuk Salmonella dan $1 \times 10^{3} \mathrm{CFU} / \mathrm{g}$ untuk Staphylococcus aureus.

Tujuan penelitian ini adalah untuk mengetahui pengaruh aplikasi edible coating berbasis pati ubi kayu diinkoorporasi dengan seng oksida (NP-ZnO) dan ekstrak bawang putih terhadap kualitas dan umur simpan pempek yang disimpan pada suhu ruang.

\section{BAHAN DAN METODE}

\section{Bahan}

Bahan yang digunakan pada penelitian ini adalah pempek komersial dari Palembang, pati ubi kayu yang diperoleh dari PT. Budi Starch dan Sweetener Tbk (Indonesia), nanopartikel ZnO (ø 20 nm) yang diperoleh dari Wako Pure Chemical Industries (Jepang), ekstrak bawang putih, gliserol, BairdParker Agar (Merck-Germany), egg yolk tellurite emulsion (Merck-Germany), buffered peptone water (Oxoid Ltd, England), Plate Count Agar (Oxoid Ltd, England), magnesium oksida, asam borat, indikator methyl red, $\mathrm{NaCl}$ (Merck, Denmark).

\section{Pembuatan ekstrak bawang putih}

Bawang putih dikupas dan dibersihkan, kemudian dihancurkan menggunakan Butchi Mixer B-400 (Switzerland). Bawang putih ditimbang dengan perbandingan $3: 4(\mathrm{~b} / \mathrm{v})$ terhadap pelarut aquades dalam erlenmeyer dan digoyang selama 6 jam menggunakan Kika Labortechnik KS 501 digital dan dimaserasi selama 18 jam. Ekstrak bawang putih disaring menggunakan kain saring.

\section{Pembuatan larutan edible coating kontrol}

Pati ubi kayu sebanyak $2 \mathrm{~g}$ dilarutkan dalam $100 \mathrm{~mL}$ akuades. Larutan pati ubi kayu diaduk menggunakan hot plate dan magnetic stirrer (MR Hei-Standard Heidolph, Germany) dan dipanaskan hingga suhu $75^{\circ} \mathrm{C}$. Kemudian gliserol ditambahkan sebanyak $20 \%$ (b/b pati ubi kayu). 


\section{Pembuatan larutan edible coating mengandung} NP-ZnO dan ekstrak bawang putih

NP-ZnO dengan konsentrasi 1 dan $3 \%$ (b/b pati) dilarutkan dalam $100 \mathrm{~mL}$ akuades mengunakan magnetic stirrer selama 5-10 menit. Pati ubi kayu sebanyak $2 \mathrm{~g}$ dimasukkan dalam larutan NP-ZnO sambil diaduk menggunakan hot plate dan magnetic stirrer dan dipanaskan hingga suhu $75^{\circ} \mathrm{C}$. Gliserol ditambahkan sebanyak $20 \%$ (b/b pati ubi kayu). Larutan didinginkan sampai suhu $50^{\circ} \mathrm{C}$ kemudian ditambahkan ekstrak bawang putih dengan konsentrasi 10, 20 dan $30 \%$ (v/v larutan).

\section{Pelapisan pempek dengan bionanokomposit}

Pempek yang dipergunakan pada penelitian ini adalah pempek lenjer, berbentuk silinder dengan ukuran diameter $2,5 \mathrm{~cm}$ dan panjang $6 \mathrm{~cm}$. Pada tahap prapenelitian ditentukan hasil coating pempek terbaik dari dua formulasi bahan edible coating berdasarkan pada hasil pembobotan data aktivitas antibakteri, nilai water vapour transmission rate, water absorption dan warna (data tidak ditampilkan), yaitu larutan coating dengan konsentrasi ZnO-NP 3\% ekstrak bawang putih 20\% (Z3B20) dan larutan coating dengan konsentrasi ZnO-NP 3\% ekstrak bawang putih 30\% (Z3B30). Pelapisan pempek lenjer dilakukan dengan mencelupkan pempek ke dalam larutan coating selama 30 detik dan dikeringanginkan. Komposisi terpilih ini dilanjutkan untuk penelitian utama. Kemudian dilakukan pengamatan kerusakan pempek mulai jam ke-0, ke-6, ke-24 dan ke48 dengan menetapkan parameter total mikroba, Staphylococcus aureus, texture profile, total nitrogen volatil, kadar air dan $\mathrm{pH}$ dengan 3 kali ulangan.

\section{Analisis total mikroba}

Analisis total mikroba menggunakan metoda (BAM, 2001). Sampel pempek sebanyak $10 \mathrm{~g}$ dihaluskan dalam stomacher dan dilarutkan dalam 90 $\mathrm{mL}$ larutan $\mathrm{NaCl}$ 0,85\% steril, sehingga didapatkan pengenceran $10^{-1}$ kemudian dilanjutkan pengenceran $10^{-2}$ hingga $10^{-4}$. Masing-masing pengenceran dipipet $1 \mathrm{~mL}$ dimasukkan dalam cawan petri steril, setiap pengenceran dipindahkan dalam 2 cawan petri. Setiap cawan petri diisi dengan $15 \mathrm{~mL}$ media Plate Count Agar (PCA) kemudian diinkubasi pada suhu $37^{\circ} \mathrm{C}$ selama 48 jam. Jumlah mikroba hidup dihitung dengan menggunakan coloni counter ( $\mathrm{K}$ \& $\mathrm{K}$ Scientific \& Medical Equipmenets Supplier, Korea Sela$\tan )$.

\section{Analisis staphylococcus aureus}

Analisis Staphylococcus aureus menggunakan metoda (BAM, 2016). Media Baird Parker Agar steril ditambahkan dengan egg yolk tellurite emulsion (Merck, Germany) dituang ke cawan petri sebanyak 15-20 mL dan dibiarkan hingga mengeras. Sampel pempek sebanyak $10 \mathrm{~g}$ dihaluskan dalam stomacher dan dilarutkan dalam $90 \mathrm{~mL}$ larutan $\mathrm{NaCl} 0,85 \%$ steril, sehingga didapatkan pengenceran $10^{-1}$, kemudian dipipet sebanyak $1 \mu \mathrm{L}$ dan diratakan di atas media menggunakan hockey stick steril yang terbuat dari kaca, diinkubasi dengan posisi cawan terbalik pada suhu $37^{\circ} \mathrm{C}$ selama 48 jam. Jumlah $S$. aureus dihitung dengan menggunakan coloni counter. Koloni S.aureus berbentuk bulat cembung berwarna hitam dengan diameter 1-5 mm dengan zona bening di sekitarnya.

\section{Texture profile analysis (TPA)}

Analisis profil tekstur menggunakan metoda (Jha et al., 2010 yang dimodifikasi). Texture Profile pempek ditetapkan menggunakan instrumen texture analyzer Brookfield Engineering Labs, Inc. (USA) dengan tipe probe TA 4/1000, beban kompresi $4.500 \mathrm{~g}$ dengan kecepatan kompresi $1 \mathrm{~mm} / \mathrm{s}$. Kompresi dilakukan pada 2 titik yang berbeda pada setiap pempek. Kekerasan sampel diperoleh dari nilai maksimum (N) rata-rata yang tercatat selama dilakukan kompresi. Parameter Texture Profile yang dianalisis meliputi hardness, adhives, cohesiveness, gumminess dan chewiness.

\section{Analisis total volatile nitrogen (TVN)}

Analisis TVN menggunakan metoda (Sulieman et al., 2012). Sampel ditimbang $10 \mathrm{~g}$ kemudian dihancurkan dalam $300 \mathrm{~mL}$ akuades dan ditambah dengan $2 \mathrm{~g}$ magnesium oksida. Labu penampung distilat diisi $25 \mathrm{~mL}$ asam borat $2 \%$ dan 2 tetes indikator methyl red. Larutan sampel didistilasi selama 25 menit. Larutan dalam labu penerima dititrasi hingga end point dengan asam sulfat $0,05 \mathrm{~N}$ terstandarisasi.

$$
\operatorname{TVN}(\mathrm{mg} / 100 \mathrm{~g})=\frac{\mathrm{V} \times \mathrm{N} \times 100 \times 14}{\mathrm{~W}}
$$

dimana, $\mathrm{W}=$ berat sampel pempek $(\mathrm{g}) ; \mathrm{V}=$ volume $\mathrm{H}_{2} \mathrm{SO}_{4}(\mathrm{~mL})$; dan $\mathrm{N}=$ normalitas $\mathrm{H}_{2} \mathrm{SO}_{4}$.

\section{Penetapan kadar air}

Analisis kadar air menggunakan metoda (AOAC, 2005). Cawan porselen yang akan digunakan dimasukkan terlebih dahulu ke dalam oven (Memmert, Germany) dengan suhu $105^{\circ} \mathrm{C}$ selama 1 jam, kemudian cawan porselen dimasukkan ke dalam desikator hingga beratnya konstan dan ditentukan beratnya. Sampel pempek sebanyak $3 \mathrm{~g}(\mathrm{~A})$ dimasukkan ke dalam cawan porselen (total berat, B) dan kemudian dimasukkan ke dalam oven selama 5 jam. Setelah itu dimasukkan ke dalam desikator dan ditimbang hingga beratnya konstan (C). Perhitungan kadar air dilakukan menggunakan formula:

$$
\text { Kadar air }(\%)=\frac{B-C}{A} \times 100 \%
$$




\section{Analisis nilai $\mathrm{pH}$}

Analisis kadar air menggunakan metoda Yunita et al. (2015). Pengecekan pH sampel pempek dilakukan dengan menggunakan pH/ORP meter $\mathrm{HI}$ 2211 Hanna Instruments (UK). Sampel pempek sebanyak $20 \mathrm{~g}$ dihancurkan menggunakan stomacher, kemudian ditambah dengan $20 \mathrm{~mL}$ akuades, $\mathrm{pH}$ sampel ditentukan menggunakan $\mathrm{pH}$ meter.

\section{Analisis statistik}

Analisis statistik penelitian ini menggunakan rancang acak lengkap (RAL) menggunakan ANOVA dan apabila hasil menunjukkan beda nyata maka dilanjutkan dengan uji Duncan's Multiple Range Test (DMRT) pada $\alpha=5 \%$. Pengujian dilakukan dengan bantuan program perhitungan IBM SPSS Statistics (Statistical Package for service solutions) versi 22.0.

\section{HASIL DAN PEMBAHASAN}

\section{Total mikroba}

Total mikroba pempek semakin meningkat dengan semakin lamanya waktu penyimpanan. Total mikroba pempek tanpa coating (kontrol) lebih banyak dibandingkan pempek yang diberi perlakuan coating (Z3B20 dan B3Z30) pada jam ke-48 (Gambar 1). Berdasarkan analisis sidik ragam, total jumlah mikroba antar perlakuan dan lamanya penyimpanan pada pempek berbeda nyata. Perubahan kenaikan jumlah mikroba dari jam ke-0 hingga jam ke-48 pada pempek kontrol dan pempek yang dicoating masing-masih sebesar 5,50 log CFU/g (kontrol), 5,15 log CFU/g dan 4,65 log CFU/g. Jumlah mikroba meningkat selama penyimpanan secara signifikan disebabkan cenderung meningkatnya aktivitas metabolisme dan pertumbuhan mikroba. O'Mahony et al. (2005) menyatakan hari ke-0 hingga dua minggu adalah masa pertumbuhan bakteri, umur dua minggu hingga empat minggu aktivitas mikroba terjadi optimal.

Hasil penelitian ini selaras dengan penelitian Karneta et al. (2013) dan Baehaki et al. (2019) pada pempek lenjer menunjukkan adanya peningkatan total mikroba dengan semakin tingginya suhu dan lama penyimpanan. Akan tetapi, bertentangan dengan hasil penelitian Warsiki et al. (2013) pada bakso ikan yang diberi perlakuan coating agar-agar atau karagenan dan ekstrak bawang putih menunjukkan penurunan jumlah mikroba dibandingkan perlakuan tanpa bahan antimikroba (ekstrak bawang putih) selama penyimpanan karena zat aktif yang ada di dalam ekstrak bawang putih menghambat partumbuhan mikroba. Hal ini dapat dijelaskan bahwa pertumbuhan mikroba selama penyimpanan disebabkan oleh ketersediaan komponen organik yang terdapat pada pempek, terutama protein, karbohidrat dan air. Perbedaan komposisi nutrisi bakso dari pempek dapat terjadi sehingga memberikan hasil pertumbuhan mikroorganisme yang berbeda.

Pertumbuhan mikroba dalam makanan menghasilkan beragam metabolit atau produk samping yang berasosiasi dengan karaktersitik kerusakan (Karneta et al., 2013). Berdasarkan Badan Standardisasi Nasional (BSN) SNI 7388:2009 bahwa batas maksimum cemaran mikroba untuk ikan dan produk olahannya adalah $5 \times 10^{5} \mathrm{CFU} / \mathrm{g}(5,70 \mathrm{log} \mathrm{CFU} / \mathrm{g})$. Hasil penelitian menunjukkan bahwa pempek kontrol dan pempek yang dicoating pada penyimpanan suhu ruang selama 6 jam dan 24 jam masa simpan masih layak untuk dikonsumsi dengan total mikroba pada jam ke-6 masing-masing 1,99 log CFU/g (kontrol), 2,62 log CFU/g (Z3B20) dan 2,84 log CFU/g (Z3B30) dan total mikroba pada jam ke-24 masingmasing 5,29 log CFU/g (kontrol), 5,30 log CFU/g (Z3B20) dan 5,66 log CFU/g (Z3B30).

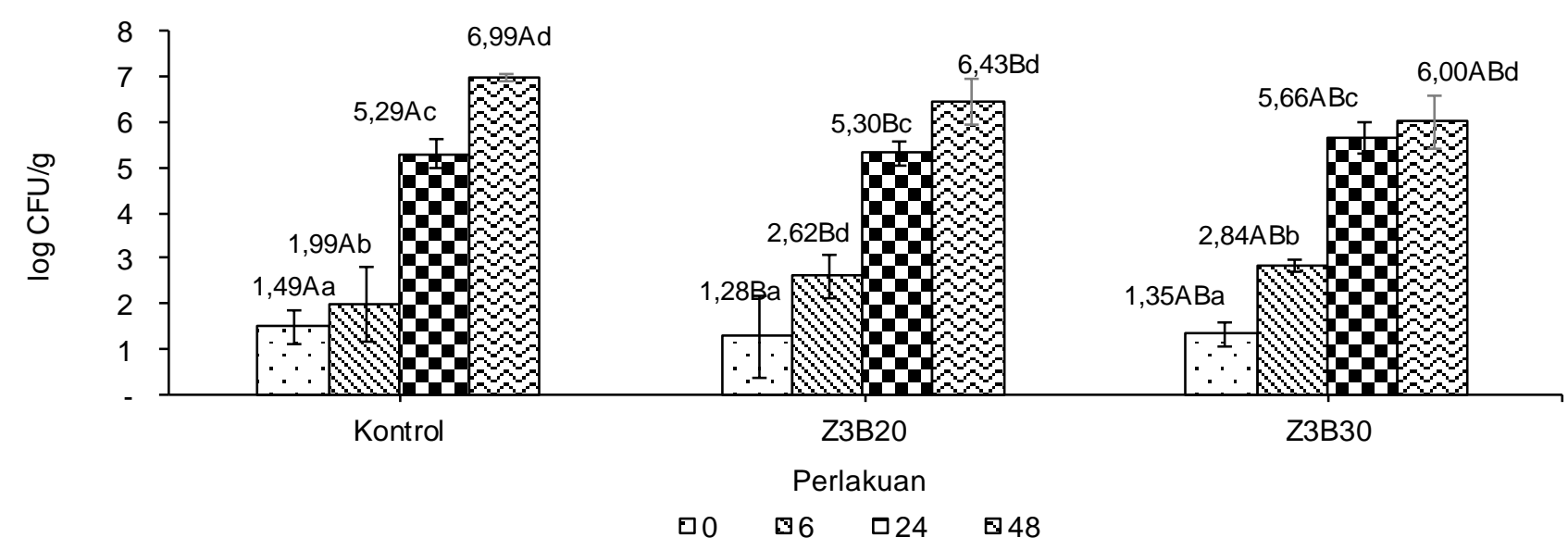

Keterangan: Perbedaan huruf di belakang nilai rata-rata pada kolom yang samamenunjukkan perbedaan nyata antar perlakuan $(A, A B, B)$ dan perbedaan nyata antar lamanya penyimpanan (a-d) 
Pada proses pengolahan pempek, seperti perebusan, memerlukan suhu yang tinggi sehingga dapat menyebabkan kerusakan fisikokimia pempek antara lain denaturasi protein dan gelatinisasi pati. Gelatinisasi pati meregangkan misela sehingga lebih banyak air terperangkap dalam granula mengakibatkan ukuran granula membesar (Kusnandar, 2010). Ketika granula terdisintegrasi, molekul amilosa keluar dari granula. Pada saat pendinginan sebelum proses coating pempek dilakukan, amilosa dapat bergabung dengan cepat membentuk kristal tidak larut disertai dengan sineresis sebagai air bebas. Kondisi ini meningkatkan peluang mikroba untuk tumbuh pada pempek.

\section{Total Staphylococcus aureus}

Hasil uji $S$. aureus menggunakan media BPA dan egg yolk tellurite menunjukkan hasil yang positif, ditandai dengan koloni yang tumbuh berwarna hitam, cembung dan timbul zona bening di sekitar koloni. Berdasarkan analisis ragam jumlah koloni $S$. aureus berbeda nyata selama waktu penyimpanan. Perubahan jumlah koloni dari jam ke-24 ke jam 48 masing-masing untuk kontrol meningkat 0,37 log CFU/g, tetapi jumlah mikroba untuk Z3B20 menurun sebesar 0,99 log CFU/g dan untuk Z3B30 menurun sebesar $0,21 \log \mathrm{CFU} / \mathrm{g}$ (Tabel 1). Pertumbuhan $S$. aureus lebih cepat pada pempek yang disimpan dalam suhu ruang dengan masa simpan 16 jam (Pratama et al. (2015); Pratama et al. (2016)) karena suhu optimum pertumbuhan $S$. aureus berkisar antara $30-37^{\circ} \mathrm{C}$ (Valero et al., 2009). Batas maksimum yang dibatasi oleh BPOM untuk keberadaan $S$. aureus pada pempek adalah $3 \mathrm{log} C F U / g$. Hasil penelitian Pratama et al. (2016) dan Warsiki et al. (2015) juga menunjukkan peningkatan jumlah $S$. aureus pada pempek selama penyimpanan yang mengindikasikan pertumbuhan $S$. aureus. Pertumbuhan $S$. aureus pada pempek seiring dengan penurunan nutrisi pempek terutama protein dari 18,26 menjadi $10,36 \%$.

Tabel 1. Total Staphylococcus aureus pada pempek

\begin{tabular}{lcccc}
\hline \multirow{2}{*}{ Perlakuan } & \multicolumn{4}{c}{ Total Staphylococcus aureus (log CFU/g) } \\
& 0 & 6 & 24 & 48 \\
\cline { 2 - 5 } & - & - & $3,68 \pm 0,39^{\mathrm{C}}$ & $4,05 \pm 0,02^{\mathrm{D}}$ \\
\hline Kontrol & - & - & $3,92 \pm 0,28^{\mathrm{C}}$ & $2,93 \pm 0,32^{\mathrm{D}}$ \\
Z3B20 & - & - & $3,85 \pm 0,38^{\mathrm{C}}$ & $3,64 \pm 0,06^{\mathrm{D}}$ \\
Z3B30 & - & - &
\end{tabular}

Keterangan:(-) = tidak ada bakteri yang tumbuh. Perbeda-

an huruf di belakang nilai rata-rata pada kolom yang sama menunjukkan perbedaan nyata antar perlakuan

Total $S$. aureus pada penelitian ini lebih tinggi diperoleh dari pempek kontrol dibanding pempek yang diberi coating dikarenakan pada pempek kontrol tidak ada barrier (penghalang) seperti pempek yang mengalami coating. Salah satu fungsi coating adalah sebagai barrier masuknya bakteri ke dalam produk pangan. Selain itu edible coating yang mengandung NP-ZnO dan ekstrak bawang putih ditemukan memiliki aktivitas antibakteri (Espitia et al., 2013, Sari et al., 2013).

Terdapat tiga mekanisme dari nanopartikel sebagai antibakteri, yang pertama NPs-ZnO akan melakukan penetrasi ke dalam sel bakteri melalui lubang atau tonjolan pada dinding sel yang akan menyebabkan dinding sel terganggu dan rusak sehingga sel akan menjadi lisis. Mekanisme yang kedua adalah dengan cara NP-ZnO akan menginduksi terbentuknya spesies oksigen reaktif (ROS) seperti superoksida anion $\left(\mathrm{O}_{2}\right)$, hidrogen peroksida $\left(\mathrm{H}_{2} \mathrm{O}_{2}\right)$ dan hidroksida $\left(\mathrm{OH}^{-}\right)$. Oksigen reaktif ini memengaruhi kerusakan komponen selular seperti lemak, DNA dan protein sehingga sel akan menjadi rusak (Sirelkhatim et al., 2015). Mekanisme yang terakhir dengan cara NP-ZnO akan berinteraksi dengan sulfur dan fosfor pada senyawa seperti DNA, sehingga sel akan mengalami kehilangan kemampuan untuk replikasi dan akan mencegah pertumbuhan dari sel bakteri (Arabi et al., 2012).

\section{Tekstur}

Hardness merupakan puncak gaya/beban maksimum pada tekanan pertama atau pada gigitan pertama, dengan satuan $\mathrm{kg}, \mathrm{g}$ atau $\mathrm{N}$ (Indiarto et al., 2012). Nilai hardness dari jam ke-6 sampai jam ke48 pada sampel kontrol meningkat sebesar $3,18 \mathrm{~N}$ dan pempek dengan coating Z3B20 sebesar 3,10 N sedangkan pada pempek dengan coating Z3B30 meningkat sebesar $5,01 \mathrm{~N}$ dari jam ke-0 sampai dengan jam ke-24 (Tabel 2).

Nilai hardness pada pempek yang diberi perlakuan coating lebih tinggi dibanding pada pempek kontrol $(9,93 \mathrm{~N})$ masing-masing sebesar 10,01 N (Z3B20) dan 13,15 N (Z3B30) namun adhesiveness, cohesiveness, gumminess dan chewiness tidak berbeda nyata. Hasil penelitian Alotaibi dan Tahergorabi (2018) pada udang yang diberi coating berbahan sweet potato starch mengandung thyme essential oil memiliki nilai hardness lebih tinggi dibandingkan dengan sampel tanpa coating, kecuali pada hari pertama. Udang yang diberi coating memiliki nilai hardness lebih tinggi selama penyimpanan. Hal ini disebabkan oleh pertumbuhan populasi bakteri pada pempek yang diberi coating lebih rendah dibanding pempek kontrol. Aktivitas bakteri dapat menyebabkan pembusukan pada makanan dari produk olahan ikan terutama bakteri asam laktat yang dapat mengubah sifat sensori selama penyimpanan produk olahan ikan. Bakteri asam laktat dan bakteri Gram negatif menghasilkan $\mathrm{H}_{2} \mathrm{~S}$ selama pertumbuhan sehingga menimbulkan bau yang sangat menyengat. Nilai hardness tinggi juga terjadi akibat agregasi disertai dengan kehilangan air yang disebabkan oleh denaturasi fraksi myofibril (Farajzadeh et al., 2016). 
Perubahan tekstur juga disebabkan oleh peningkatan bakteri mesofilis aerobik yang ditandai dengan peningkatan total mikroba pempek dengan semakin meningkatnya suhu dan lamanya penyimpanan, demikian pula adanya interaksi antara coating dengan jaringan permukaan sampel (Jiang et al., 2011).

\section{Total volatile nitrogen (TVN)}

TVN merupakan parameter untuk menentukan kemunduran mutu ikan atau produk olahan ikan yang mengandung protein. Peningkatan konsentrasi TVN pempek pada kontrol sebesar $5,69 \mathrm{mg} / 100 \mathrm{~g}$, pada pempek yang diberi coating Z3B20 sebesar $7,88 \mathrm{mg} / 100 \mathrm{~g}$ dan pempek yang diberi coating Z3B30 sebesar 2,39 mg/100 g (Tabel 3). Peningkatan konsentrasi TVN pada pempek disebabkan oleh peningkatan jumlah total mikroba serta jumlah $S$. aureus pada pempek. Hasil penelitian Pratama et al. (2016) pada pempek lenjer juga menunjukkan adanya peningkatan TVN selama penyimpanan selama 24 jam pada kondisi kemasan tidak vakum dan suhu ruang. Demikian pula hasil penelitian Karneta et al. (2013) pada pempek lenjer menunjukkan adaya peningkatan TVN dengan semakin tingginya suhu dan lama penyimpanan.

Menurut Songsaeng et al. (2010), peningkatan nilai TVN sebagai akibat dari pertumbuhan mikroba yang semakin cepat yang terlibat dalam produksi basa volatil. Bakteri mendegradasi protein dan turunannya menjadi basa volatil seperti ammonia, trimetilamin, histamin, indol, $\mathrm{H}_{2} \mathrm{~S}$ dan skatol, dan menguraikan trimetil amin oksida menjadi trimetil amin (Karneta et al., 2013). TVN terbentuk selama penyimpanan pempek (Jinadasa, 2014). Pempek dengan edible coating mampu melindungi produk dari terbentuknya basa volatil yang tidak diinginkan.

Kadar TVN maksimal produk makanan yang dapat diterima sebesar $20 \mathrm{mg} / 100 \mathrm{~g}$ (Castro et al., 2012), tidak boleh lebih 30-35 mg/100 g dalam daging ikan (Amegovu et al., 2012). Jika berdasarkan parameter TVN dan total mikroba, pempek yang di- beri coating yang disimpan selama 48 jam masih layak untuk dikonsumsi karena maksimal kandungan TVN pada sampel selama penyimpanan sebesar $18,94 \mathrm{mg} / 100 \mathrm{~g}$.

Tabel 3. Nilai kadar air, pH dan total volatile nitrogen (TVN) pada sampel pempek

\begin{tabular}{|c|c|c|c|c|}
\hline Sampel & $\begin{array}{l}\text { Waktu } \\
\text { jam ke- }\end{array}$ & $\begin{array}{l}\text { Kadar } \\
\text { Air } \%\end{array}$ & $\mathrm{pH}$ & $\begin{array}{c}\text { TVN } \\
(\mathrm{mg} / 100 \mathrm{~g})\end{array}$ \\
\hline \multirow[t]{4}{*}{ Kontrol } & 0 & $\begin{array}{c}56,80 \pm \\
5,64^{\mathrm{a}}\end{array}$ & $\begin{array}{l}6,87 \pm \\
0.05^{\mathrm{b}}\end{array}$ & $\begin{array}{c}11,64 \pm \\
0.67^{\mathrm{a}}\end{array}$ \\
\hline & 6 & $\begin{array}{c}59,62 \pm \\
3,03^{a}\end{array}$ & $\begin{array}{l}6,86 \pm \\
0,05^{b}\end{array}$ & $\begin{array}{c}12,64 \pm \\
0,27^{\mathrm{a}}\end{array}$ \\
\hline & 24 & $\begin{array}{c}60,13 \pm \\
1,59^{\mathrm{ab}}\end{array}$ & $\begin{array}{l}6,89 \pm \\
0,05^{a}\end{array}$ & $\begin{array}{c}17,33 \pm \\
1,10^{\mathrm{c}}\end{array}$ \\
\hline & 48 & $\begin{array}{c}64,06 \pm \\
1,65^{\mathrm{b}}\end{array}$ & $\begin{array}{l}6,62 \pm \\
0,05^{a}\end{array}$ & $\begin{array}{c}15,10 \pm \\
0,57^{\mathrm{b}}\end{array}$ \\
\hline \multirow[t]{4}{*}{ Z3B20 } & 0 & $\begin{array}{c}56,80 \pm \\
5,64^{\mathrm{a}}\end{array}$ & $\begin{array}{l}6,87 \pm \\
0,05^{b}\end{array}$ & $\begin{array}{c}11,64 \pm \\
0,67^{\mathrm{a}}\end{array}$ \\
\hline & 6 & $\begin{array}{c}58,54 \pm \\
2,28^{\mathrm{a}}\end{array}$ & $\begin{array}{l}6,84 \pm \\
0,01^{b}\end{array}$ & $\begin{array}{c}11,56 \pm \\
0,41^{\mathrm{a}}\end{array}$ \\
\hline & 24 & $\begin{array}{l}61,80 \pm \\
2,22^{\mathrm{ab}}\end{array}$ & $\begin{array}{l}6,60 \pm \\
0,06^{a}\end{array}$ & $\begin{array}{c}18,94 \pm \\
0,41^{\mathrm{c}}\end{array}$ \\
\hline & 48 & $\begin{array}{c}62,97 \pm \\
2,36^{\mathrm{b}}\end{array}$ & $\begin{array}{l}6,68 \pm \\
0,08^{a}\end{array}$ & $\begin{array}{c}15,64 \pm \\
0,55^{\mathrm{b}}\end{array}$ \\
\hline \multirow[t]{4}{*}{ Z3B30 } & 0 & $\begin{array}{c}56,80 \pm \\
5,64^{\mathrm{a}}\end{array}$ & $\begin{array}{l}6,87 \pm \\
0,05^{b}\end{array}$ & $\begin{array}{c}11,64 \pm \\
0,67^{\mathrm{a}}\end{array}$ \\
\hline & 6 & $\begin{array}{c}60,13 \pm \\
0,89^{\mathrm{a}}\end{array}$ & $\begin{array}{l}6,90 \div \\
0,01^{\mathrm{b}}\end{array}$ & $\begin{array}{c}12,38 \pm \\
0,24^{\mathrm{a}}\end{array}$ \\
\hline & 24 & $\begin{array}{l}62,44 \pm \\
2,75^{\mathrm{ab}}\end{array}$ & $\begin{array}{l}6,41 \pm \\
0,15^{a}\end{array}$ & $\begin{array}{c}14,50 \pm \\
0,54^{\mathrm{C}}\end{array}$ \\
\hline & 48 & $\begin{array}{c}62,05 \pm \\
1,99^{\mathrm{b}}\end{array}$ & $\begin{array}{l}6,58 \pm \\
0,03^{a}\end{array}$ & $\begin{array}{c}14,80 \pm \\
1,40^{\mathrm{b}}\end{array}$ \\
\hline
\end{tabular}

Keterangan: Perbedaan huruf di belakang nilai rata-rata pada kolom yang sama menunjukkan perbedaan nyata antar perlakuan

\section{Kadar air}

Kadar air pempek kontrol pada penyimpanan hingga jam ke-48 meningkat sebesar 7,26\%. Peningkatan ini lebih besar daripada kadar air pempek yang diberi coating Z3B20 (6,17\%) dan Z3B30 $(5,25 \%)$ (Tabel 2).

Tabel 2. Tekstur pada sampel pempek

\begin{tabular}{ccccccc}
\hline \multirow{2}{*}{ Sampel } & Waktu & \multicolumn{5}{c}{ Texture Profile } \\
\cline { 2 - 6 } & Jam ke- & Hardness $(\mathrm{N})$ & Adhesiveness & Cohesiveness & Gumminess (N) & Chewiness(N) \\
\hline Kontrol & 0 & $9,55 \pm 2,46^{\mathrm{D}}$ & $0,31 \pm 0,37^{\mathrm{a}}$ & $0,82 \pm 0,02^{\mathrm{a}}$ & $7,96 \pm 2,23^{\mathrm{a}}$ & $7,06 \pm 1,76^{\mathrm{a}}$ \\
& 6 & $6,75 \pm 3,37^{\mathrm{a}}$ & $0,12 \pm 0,12^{\mathrm{a}}$ & $0,85 \pm 0,01^{\mathrm{a}}$ & $5,79 \pm 3,50^{\mathrm{a}}$ & $4,97 \pm 2,90^{\mathrm{a}}$ \\
& 24 & $8,50 \pm 0,55^{\mathrm{D}}$ & $0,61 \pm 0,76^{\mathrm{a}}$ & $0,81 \pm 0,01^{\mathrm{a}}$ & $6,70 \pm 0,60^{\mathrm{a}}$ & $6,27 \pm 0,68^{\mathrm{a}}$ \\
& 48 & $9,93 \pm 1,33^{\mathrm{D}}$ & $0,40 \pm 0,05^{\mathrm{a}}$ & $0,86 \pm 0,03^{\mathrm{a}}$ & $8,69 \pm 1,54^{\mathrm{a}}$ & $7,77 \pm 1,32^{\mathrm{a}}$ \\
Z3B20 & 0 & $10,27 \pm 1,73^{\mathrm{D}}$ & $0,65 \pm 0,71^{\mathrm{a}}$ & $0,83 \pm 0,01^{\mathrm{a}}$ & $8,53 \pm 1,69^{\mathrm{a}}$ & $7,41 \pm 1,76^{\mathrm{a}}$ \\
& 6 & $6,91 \pm 0,23^{\mathrm{a}}$ & $0,17 \pm 0,02^{\mathrm{a}}$ & $0,80 \pm 0,01^{\mathrm{a}}$ & $5,66 \pm 0,08^{\mathrm{a}}$ & $4,78 \pm 0,35^{\mathrm{a}}$ \\
& 24 & $7,25 \pm 0,62^{\mathrm{D}}$ & $0,85 \pm 0,34^{\mathrm{a}}$ & $0,85 \pm 0,01^{\mathrm{a}}$ & $6,28 \pm 0,54^{\mathrm{a}}$ & $5,36 \pm 0,15^{\mathrm{a}}$ \\
& 48 & $10,01 \pm 1,46^{\mathrm{D}}$ & $0,70 \pm 0,17^{\mathrm{a}}$ & $0,85 \pm 0,00^{\mathrm{a}}$ & $8,74 \pm 1,45^{\mathrm{a}}$ & $8,13 \pm 1,35^{\mathrm{a}}$ \\
Z3B30 & 0 & $8,14 \pm 1,34^{\mathrm{D}}$ & $0,32 \pm 0,11^{\mathrm{a}}$ & $0,82 \pm 0,04^{\mathrm{a}}$ & $6,78 \pm 1,05^{\mathrm{a}}$ & $5,92 \pm 1,10^{\mathrm{a}}$ \\
& 6 & $9,23 \pm 2,88^{\mathrm{a}}$ & $0,46 \pm 0,45^{\mathrm{a}}$ & $0,82 \pm 0,01^{\mathrm{a}}$ & $7,81 \pm 3,09^{\mathrm{a}}$ & $6,91 \pm 2,53^{\mathrm{a}}$ \\
& 24 & $13,15 \pm 0,97^{\mathrm{D}}$ & $0,69 \pm 0,47^{\mathrm{a}}$ & $0,83 \pm 0,01^{\mathrm{a}}$ & $11,02 \pm 0,94^{\mathrm{a}}$ & $9,62 \pm 0,28^{\mathrm{a}}$ \\
& 48 & $9,36 \pm 1,83^{\mathrm{D}}$ & $1,19 \pm 0,33^{\mathrm{a}}$ & $0,81 \pm 0,01^{\mathrm{a}}$ & $7,70 \pm 1,94^{\mathrm{a}}$ & $6,71 \pm 1,80^{\mathrm{a}}$ \\
\hline
\end{tabular}

Keterangan: Perbedaan huruf di belakang nilai rata-rata pada kolom yang sama menunjukkan perbedaan nyata antar perlakuan 
Hasil penelitian Sembiring (2011) juga menunjukkan adanya peningkatan kadar air pada pempek yang diberi coating mengandung kitosan dibandingkan dengan kontrol selama penyimpanan. Coating berfungsi sebagai barrier (penghalang) karena coating mengandung NP-ZnO dan ekstrak bawang putih yang bersifat hidrofilik. Peningkatan kadar air pada pempek kontrol disebabkan oleh tidak adanya barrier (penghalang) seperti pempek yang diberi coating. Akibatnya pempek kontrol tidak memiliki ketahanan terhadap gas $\mathrm{O}_{2}$ dan $\mathrm{CO}_{2}$ sehingga kelembaban udara dari lingkungan masuk ke dalam poripori pempek dan menjadikan pempek lebih basah. Kenaikan kadar air pada pempek yang diberi coating tidak sebesar peningkatan pada kontrol, bahkan ada yang menurun. Hal ini disebabkan oleh adanya bahan pengisi coating seperti NP-ZnO dan ekstrak bawang putih yang bersifat hidrofilik. Inkorporasi NP$\mathrm{ZnO}$ dalam edible coating dapat mengurangi kapasitas absorpsi air (Andiyana et al., 2016). Penambahan ekstrak bawang putih pada edible coating dari pati ubi kayu juga dapat melemahkan ikatan antar molekul amilosa sehingga menurunkan kemampuan jaringan untuk mengikat air sehingga air bebas yang berada dalam material coating mudah menguap selama proses pengeringan (Sari et al., 2013).

\section{Nilai pH}

Nilai $\mathrm{pH}$ pempek mengalami penurunan pada semua sampel (Tabel 3). Penurunan pH selama penyimpanan disebabkan penetrasi gas yang bersifat asam yang dihasilkan oleh degradasi protein oleh bakteri $S$. aureus pada pempek (Pratama et al., 2016), adanya produksi asam yang dihasilkan dari respirasi sel bakteri, dalam alur glikolisis menghasilkan asam karboksilat yang mengkontaminasi pempek (Petkova et al., 2013). Pada proses pembusukan ikan dan produk olahan ikan, perubahan $\mathrm{pH}$ daging ikan disebabkan oleh proses autolisis dan penyerangan bakteri. Secara umum bakteri tumbuh lebih cepat pada $\mathrm{pH}$ 6,0-8,0, khamir pada $\mathrm{pH} 4,5-6,0$ dan kapang pada $\mathrm{pH} 3,5-4,0$; kecuali pada bakteri yang memproduksi asam sebagai hasil metabolis menya (Fields, 1979).

Penelitian Hadi et al. (2014) juga menunjukkan penurunan nilai $\mathrm{pH}$ seiring dengan lamanya penyimpanan pada bakso daging kontrol, bakso daging yang diberi coating mengandung $1 \%$ kitosan atau yang diberi coating mengadung kitosan $1 \%$ dan penambahan ekstrak bawang putih $2 \%$ pada jam ke-0 sampai jam ke-24. Penurunan $\mathrm{pH}$ dan terbentuknya bau busuk pada sampel bakso daging control dan yang diberi coating menunjukkan adanya aktivitas mikroba fakultatif anaerob. Penelitian Warsiki et al. (2013) juga menunjukkan adanya penurunan pH pada bakso ikan yang diberi coating dengan larutan berbahan karagenan, agar, dan bawang putih berkisar 7,0-5,0 yang disebabkan oleh aktivitas mikroor- ganisme sehingga pemecahan karbohidrat menjadi asam sangat tinggi dan jumlah asam yang dihasilkan lebih banyak.

\section{KESIMPULAN}

Penambahan NP-ZnO dan ekstark bawang putih pada bahan bionanokomposit edible film yang diaplikasikan pada produk pempek memengaruhi jumlah total mikroba, jumlah koloni $S$. aureus, TVN, tekstur, kadar air dan $\mathrm{pH}$ produk sehingga efektif digunakan sebagai pengemasan produk pangan. Berdasarkan jumlah total mikroba dan nilai TVN pada pempek yang diberi coating dengan masa simpan 24 jam pada suhu ruang masih layak dikonsumsi.

\section{UCAPAN TERIMAKASIH}

Penulis mengucapkan terima kasih kepada Balai Besar Penelitian dan Pengembangan Pascapanen Pertanian, Badan Penelitian dan Pengembangan Pertanian, Kementerian Pertanian karena memfasilitasi penulis melakukan penelitian dan Kementerian Pertanian yang memberikan beasiswa untuk program Doktoral.

\section{DAFTAR PUSTAKA}

Alotaibi S, Tahergorabi R. 2018. Development of a sweet potato starch-based coating and its effect on quality attributes of shrimp during refrigerated storage. LWT-Food Sci Technol 88: 203209. DOI: 10.1016/j.Iwt.2017.10.022.

Amegovu AK, Sserunjogi ML, Ogwok P, Makokha V. 2012. Nucleotide degradation products, total volatile basic nitrogen, sensory and microbiologycal quality of nile perch (Latesniloticus) fillets under chilled storage. J Microbiol Biotech Food Sci 2: 653-666.

Andiyana Y, Suyatma NE, Suliantari. 2016. Physicomechanical properties of starch-based nanocomposite film incorporated with hydrothermally synthesized zinc oxide nanoparticles. Mater Sci Forum 872: 162-167. DOI: 10.4028/www.scienti fic.net/MSF.872.162.

Arabi $F$, Imandar $M$, Negahdary $M$, Noughabi MT, Akbari-dastjerdi H, Fazilati M. 2012. Investigation anti-bacterial effect of xinc oxide nanoparticles upon life of Listeria monocytogenes. Ann Biol Res 3: 3679-3685.

[AOAC] Association of Official Analytical Chemist. 2005. Official method of analysis of official analytical of chemist. The Association of Official Analytical Chemist, Inc. Arlington. 
Baehaki A, Nopianti R, Wati LT. 2019. Pengaruh hidrolisat kolagen dari kulit ikan patin (Pangasius pangasius) terhadap umur simpan pempek ikan gabus (Channa striata). J Agroind Halal 5: 67-74.

[BAM] Bacteriological Analytical Manual. 2001. BAM: Aerobic Plate Count. https://www.fda.gov /food/foodscienceresearch/laboratorymethods/u cm2006949.htm [19 April 2018].

[BAM] Bacteriological Analytical Manual. 2016. BAM: Staphylococcus aureus. https://www.epa. gov/sites/production/files/2015-07/documents/fd a-bam-appendix1.pdf [19 April 2018].

Castro P, Millan R, Penedo JC, Sanjuan E. 2012. Effect of storage conditioning on total volatile base nitrogen determinations in fish muscle extracts. J Aquat Food Prod T 21: 519-523. DOI: 10.1080/10498850.2011.610917.

Espitia PJP, Soares ND, Teófilo RF, dos Reis Coimbra JS, Vitor DM, Batista RA, Ferreira SO, de Andrade NJ, Medeiros EAA. 2013. Physicalmechanical and antimicrobial properties of nanocomposite films with pediocin and $\mathrm{ZnO}$ nanoparticles. Carbohyd Polym 94: 199-208. DOI: 10.1016/j.carbpol.2013.01.003.

Farajzadeh F, Motamedzadegan A, Shahidi S. 2016. The effect of chitosan-gelatin coating on the quality of shrimp (Litopenaeus vannamei) under refrigerated condition. Food Control 67: 163170. DOI: 10.1016/j.foodcont.2016.02.040.

Fields ML. 1979. Foundamentals of Food Microbiology. 625. New York: Mc. Graw Hill Book Co.

Garcia NL, Ribbon L, Dufresne A, Aranguren M, Goyanes S. 2011. Effect of glycerol on the morphology of nanocomposites made from thermoplastic starch and starch nanocrystals. Carbohyd Polym 84: 203-210. DOI: 10.1016/j.carbpol. 2010.11.024.

Hadi HNSS, Suyatma NE, Syarief R. 2014. Aplikasi kitosan dengan penambahan ekstrak bawang putih sebagai pengawet dan pelapis edible bakso sapi. J Sains Terapan 4: 35-45.

Indiarto R, Nurhadi B, Subroto E. 2012. Kajian karakteristik tekstur (Texture profil analysis) dan organoleptik daging ayam asap berbasis teknologi asap cair tempurung kelapa. J Teknol Hasil Pertanian 5: 106-116.

Jha SK, Sethi S, Srivatav M, Dubey AK, Sharma RR, Samuel DVK, Singh AK. 2010. Firmness characteristics of mango hybrids under ambient storage. J Food Eng 97: 208-212. DOI: 10.101 6/j.jfoodeng.2009.10.011.

Jiang M, Liu S, Wang Y. 2011. Effects of antimicrobial coating from catfish skin gelatin on quality and shelf life of fresh white shrimp (Penaeus vannamei). J Food Sci 76: 204-209. DOI: 10.11 11/j.1750-3841.2011.02056.x.

Jinadasa BKKK. 2014. Determination of quality of marine fishes based on total volatile base nitrogen test (TVB-N). Nat Sci 12: 106-111.

Karneta R, Rejo A, Priyanto G, Pambayun R. 2013. Difusivitas panas dan umur simpan pempek lenjer. J Keteknikan Pertanian 1: 131-141. DOI: 10.19028/jtep.01.1.131-141.

O'Mahony JA, Lucey JA, McSweeney PL. 2005. Chymosin-mediated proteolysis, calcium solubilization, and texture development during the ripening of cheddar cheese. J Dairy Sci 88: 3101-3114. DOI: 10.3168/jds.S0022-0302(05)7 2992-1.

Petkova V, Obreshkova D, Vodenicharov E, Hadjieva B, Koleva N, Petkova E, Dimitrov M. 2013. Essential amino acids-review of some of the contemporary analytical methods for detection. Word J Pharm Pharm Sci 2: 658-666.

Pratama M, Warsiki E, Haditjaroko L. 2015. Identification of phenol red as Staphylococcus aureus indicator label. Proceeding of Int. Conference on Adaptive and Intelligent Agroindustry. Bogor, 3-4 Agustus 2015. 206-209.

Pratama M, Warsiki E, Haditjaroko L. 2016. Kinerja label untuk memprediksi umur simpan pempek pada berbagai kondisi penyimpanan. J Teknol Industri Pertanian 26: 321-332.

Rosdiana. 2002. Pengaruh Penyimpanan dan Pemasakan terhadap Mutu Gizi dan Organoleptik Empek-Empek. [Tesis]. Bogor: Fakultas Teknologi Pertanian, Institut Pertanian Bogor.

Rathore A, Pradhan MK. 2017. Hybrid cellulose bionanocomposites from banana and jute fibre - a review of preparation, properties and applications. Mater Today-Proc 4: 3942-3951. DOI: 10. 1016/j.matpr.2017.02.294.

Sari RP, Wulandari ST, Wardhani DH. 2013. Pengaruh penambahan ekstrak bawang putih (Allium sativum) terhadap karakteristik edible film pati ganyong (Canna edulis Kerr). J Teknol Kimia Industri 2: 82-87.

Sembiring WB. 2011. Penggunaan Kitosan sebagai Pembentukan Gel dan Edible Coating serta Pengaruh Penyimpanan Suhu Ruang terhadap mutu dan Daya Awet Empek-Empek. [Skripsi]. Bogor: Fakultas Teknologi Pertanian, Institut Pertanian Bogor.

Sirelkhatim A, Mahmud S, Seeni A, Kaus NHM, Ann LC, Bakhori SKM, Hasan H, Mohamad D. 2015. Review on zinc oxide nanoparticles: antibacterial activity and toxicity mechanism. Nano-Micro Lett 7: 219-242. DOI: 10.1007/s40820-0150040-x. 
Songsaeng S, Sophanodora P, Kaewsrithong J, Ohshima T. 2010. Effect of different storage conditions on quality of white-scar oyster (Crassostrea belcheri). Int Food Res J 17: 491-500.

Sulieman HMA, Bari LOA, Hafiz MA. 2012. Determination of quality and shelf life of three marine fishes (coral trout, greasy grouper and red mouthed bream) based on total volatile nitrogen test (TVN). Int J Livest Res 2: 227-235

Valero A, Pérez-Rodríguez F, Carrasco E, FuentesAlventosa JM, García-Gimeno RM, Zurera G. 2009. Modelling the growth boundaries of Staphylococcus aureus: Effect of temperature, $\mathrm{pH}$ and water activity. Int $J$ Food Microbiol 133: 186-194. DOI: 10.1016/j.ijfoodmicro.2009.05. 023
Warsiki E, Sunarti TC, Nurmala L. 2013. Kemasan antimikrob untuk memperpanjang umur simpan bakso ikan. J Ilmu Pertanian Indonesia 18: 125131.

Warsiki E, Rahayuningsih M, Haditjaroko L, Pratama M. 2015. Kemasan berindikator sebagai pemantau kualitas pempek. Prosiding Seminar Hasil-Hasil PPM IPB 1: 192-200.

Yunita M, Hendrawan Y, Yulianingsih R. 2015. Analisis kuantitatif mikrobiologi pada makanan penerbangan (aerofood ACS) Garuda Indonesia berdasarkan TPC (Total Plate Count) dengan metode pour plate. J Keteknikan Pertanian Trop Biosis 3: 237-248. 